\title{
Influence of predation risk and food supply on nocturnal fish foraging distributions along a mangrove-seagrass ecotone
}

\author{
Neil Hammerschlag ${ }^{1,2, *}$, Michael R. Heithaus ${ }^{3}{ }$ Joseph E. Serafy ${ }^{1,4}$ \\ ${ }^{1}$ Rosenstiel School of Marine and Atmospheric Science, University of Miami, 4600 Rickenbacker Causeway, Miami, \\ Florida 33149, USA \\ ${ }^{2}$ RJ Dunlap Marine Conservation Program, University of Miami, 4600 Rickenbacker Causeway, Miami, Florida 33149, USA \\ ${ }^{3}$ Department of Biological Sciences, Florida International University, 3000 NE 151 St., North Miami, Florida 33181, USA \\ ${ }^{4}$ National Oceanic and Atmospheric Administration, National Marine Fisheries Service, Southeast Fisheries Science Center, \\ 75 Virginia Beach Drive, Miami, Florida 33149, USA
}

\begin{abstract}
Diverse taxa from many systems must make tradeoffs between food and safety. However, few studies have examined the response of multiple fish species to food and predation risk at night across their foraging landscape. In Biscayne Bay, Florida (USA), we investigated the influences of food and predation risk on nocturnal habitat use of gray snapper, bluestriped grunt and seabream along a distance gradient spanning from the mangrove-seagrass ecotone to $120 \mathrm{~m}$ offshore. Seine and submerged vegetation sampling were used to determine the distribution of fishes and their food resources. Tethering experiments were used to explore gradients in predator encounter rates. We used these data to test the following a priori predictions of fish distributions relative to food and risk as generated from foraging theory: (1) fishes will be distributed in proportion to their food supply (i.e. ideal free distribution, IFD); or (2) fishes will avoid high-risk areas such that their abundances will be lower than predicted by food resources in high-risk habitats (i.e. food-risk tradeoff). Results indicated that none of the fishes were distributed according to IFD. Seabream and gray snapper avoided foraging close to shore, where their food was abundant, but risk was highest. Bluestriped grunt responses to spatial variation in food supply and risk were less clear; they appeared to forage randomly across the distance gradient. Our results suggest that fish generally avoid the risky mangrove-seagrass ecotone, but responses to variation in food and risk are species-specific and may be dependent on specific anti-predator tactics or influenced by factors we did not measure.
\end{abstract}

KEY WORDS: Predators $\cdot$ Edge effects $\cdot$ Proximity gradient $\cdot$ Shark $\cdot$ Snapper $\cdot$ Porgy $\cdot$ Grunt

\section{INTRODUCTION}

Predators can affect prey distribution and abundance through direct predation (Krebs \& Davies 1984) and non-consumptive or 'risk' effects, such as alteration of prey behavior and habitat use (Werner et al. 1983, Brown 1999, Creel \& Christianson 2008). While foraging, most animals are susceptible to predation because behaviors that enhance foraging opportunities typically also increase predation risk (e.g. increased activity levels; discussed by Lima \& Dill 1990, Lima 1998). Moreover, habitats that contain the great- est food resources are often the most dangerous (Sih 1980, Brown 1988, Brown \& Kotler 2004). Thus, a tradeoff often exists between foraging opportunities and the risk of predation (Sih 1980, Lima \& Dill 1990, Houston et al. 1993). By sacrificing feeding rate for safety (e.g. shifting to safer but less profitable feeding patches) in response to risk, consumers can impact the behaviors and abundances of other organisms, which can initiate trophic cascades (Creel \& Christianson 2008, Heithaus et al. 2008). Thus, understanding how organisms respond to food-risk tradeoff is important for predicting how these individuals and their commu- 
nities are likely to respond to anthropogenic impacts (discussed by Morris 2003, Frid et al. 2008, Heithaus et al. 2008).

Behavioral optimization theory and associated models provide a theoretical framework, which is applicable across taxa and systems, for studying the influence of food availability and predation risk on forager habitat use. The ideal free distribution (IFD; Fretwell \& Lucas 1970) is the basis of many habitat selection models and can be used as a null model for assessing factors influencing habitat use during foraging, including predation risk (e.g. van Baalen \& Sabelis 1993, Heithaus et al. 2007b, Wirsing et al. 2008). The basic IFD model predicts that foragers will be distributed across habitat patches in proportion to their food supply (Fretwell \& Lucas 1970) and, therefore, the densities of foragers relative to their food availability (i.e. the ratio of foragers relative to their food availability) should be equal across habitats (Heithaus et al. 2007b, Wirsing et al. 2007). If predation risk varies across habitats, however, many foragers will forego foraging opportunities to enhance their safety (see Lima \& Dill 1990, Lima 1998, Brown \& Kotler 2004 for reviews). This should lead to relative densities of foragers in safer habitats being greater than they would be in the absence of predation risk (e.g. in dolphins Tursiops aduncus, Heithaus \& Dill 2002; in perch Perca fluviatilis, Bystrom et al. 2003; in elk Cervus elaphus, Ripple \& Beschta 2007; in harbor seals Phoca vitulina, Frid et al. 2007). Numerous currencies have been proposed for optimizing the tradeoff between predation risk and food availability (see Brown 1992, Brown \& Kotler 2004). In many situations, foragers (especially juveniles) may select the habitat that minimizes the ratio of predation risk $(\mu)$ to foraging rate $(f)$ (i.e. minimize $\mu / f$ ) (Gilliam \& Fraser 1987, similar to $p F$ in Brown 1992). Working in experimental streams, Gilliam \& Fraser (1987) found that foraging under predation risk in juvenile creek chub (Semotilus atromaculatus) agreed well with this model's theoretical predictions. However, because energy intake in habitats is usually density dependent, the quality of a given habitat will decline as more foragers accumulate in it, thereby increasing $\mu / f$. Therefore, foraging animals are unlikely to all select the same habitat and individuals will begin selecting higher-risk habitats when foraging rewards offset the cost of increased predation risk (Brown \& Kotler, 2004). Furthermore, some individuals may select high-risk, but high-reward, habitats even if the value of $\mu / f$ is relatively high. For example, individuals in poor body condition often accept higher risk in order to forage in high quality habitats (McNamara \& Houston 1987, Sinclair \& Arcese 1995, Lima 1998, Heithaus et al. 2007a) and some age-sex classes that can benefit from increased body condition will take greater risks in order to realize fitness gains (e.g. Cresswell 1994, Brown \& Kotler 2004).

The combined effects of food availability and predation risk on fish foraging behavior has been investigated via both laboratory (e.g. Abrahams \& Dill 1989, Grand \& Dill 1997, Dupuch et al. 2009) and field experiments (e.g. Werner et al. 1983, Dahlgren \& Eggleston 2000, Grol et al. 2008), primarily during daylight hours. In contrast, relatively little attention has been directed towards fish foraging decisions at night when many foragers emerge from refuges to feed and predators commence hunting. Moreover, most studies investigating habitat use have typically examined foraging behavior in discrete habitat patches, e.g. structurally complex 'safe' habitats versus open 'risky' habitats (Lima \& Dill 1990, Lima 1998). Few studies have examined the influences of food and risk along a habitat gradient that varies in relative safety and food availability (see Thorson et al. 1998, Laundre et al. 2001, Hernandez \& Laundre 2005, van der Merwe \& Brown 2008). In addition, relatively few studies have simultaneously investigated the spatial responses of multiple prey species of different trophic guilds to the same predators, even though most systems contain a variety of species that may respond differently to the same predators (see Vesakoski et al. 2008, Heithaus et al. 2009, Valeix et al. 2009).

Mangrove-seagrass systems provide an opportunity to study the response of multiple fish species of different trophic guilds to food availability and predation risk at night across their foraging landscape. It is well established that during daylight hours, a diverse group of fishes primarily shelter amongst mangrove prop roots (e.g. Robertson \& Blaber 1992, Laegdsgaard \& Johnson 1995, 2001). However, at night, many of these fishes disperse into adjacent seagrass beds to feed. This is supported by a variety of evidence including results from a combination of gut content analysis (Randall 1967), stable isotopes (Kieckbusch et al. 2004, Nagelkerken \& van der Velde 2004a, b), visual surveys (Rooker \& Dennis 1991, Serafy et al. 2003, 2007), seine sampling (Hammerschlag \& Serafy 2010) and tagging investigations (Verweij \& Nagelkerken 2007, Luo et al. 2009). Nocturnal selection of seagrass beds by fishes as primary feeding sites appears to be related to elevated availability and accessibility of prey, many of which emerge from the vegetated substrate at night (Mattila et al. 1999, Nagelkerken et al. 2000, Unsworth et al. 2007, Valentine et al. 2007). However, how predation risk and food supply influence fish distribution patterns within seagrass beds during foraging at night remains poorly understood (Hammerschlag et al. 2010a). Recent evidence suggests that predation risk in these systems may be relatively high, especially at night (Chittaro et al. 2005, Rypel et al. 2007, Doren- 
bosch et al. 2009) and thereby likely to influence fish distribution patterns (Dahlgren \& Eggleston 2000, Grol et al. 2008).

In the present study, we conducted sampling and observation of fishes in subtropical Biscayne Bay, Florida (USA) to investigate the combined effects of food availability and predation risk on nocturnal fish distributions in an area spanning from the mangrove-seagrass ecotone out to $120 \mathrm{~m}$ from shore in adjacent seagrass beds. To achieve this objective, we conducted an integrated set of quantitative nocturnal studies, which collectively tested a priori predictions (based on foraging theory) as to whether fishes: (1) were distributed across their foraging landscape in proportion to their food supply (i.e. according to the IFD theory; Fretwell \& Lucas 1970); or (2) avoided high-risk habitats such that relative abundances were lowest in habitats with relatively high risk and vice versa (i.e. food-risk tradeoffs; Gilliam \& Fraser 1987). Research focused on the foraging habitat use of 3 fish species representing different trophic guilds: the gray snapper Lutjanus griseus (generalist zoobenthivore), the bluestriped grunt Haemulon sciurus (crustacean zoobenthivore) and the seabream Archosargus rhomboidalis (herbivore).

\section{MATERIALS AND METHODS}

Study area. This study was conducted in an area along the leeward side of Elliott Key, between 25.43 and $25.40^{\circ} \mathrm{N}$ at the eastern boundary of southern Biscayne Bay, Florida, USA (Fig. 1). The shoreline is fringed by a continuous band of red mangroves
Fig. 1. Study area. (A) Location of Biscayne Bay in Florida; (B) position of study area ( $\square$ ) on leeward side of Elliott Key within Biscayne Bay; (C) location of 3 sampling transects ( $\mathrm{T} 1$, T2, T3) within the study area; and (D) diagram of a single $120 \mathrm{~m}$ transect with $20 \mathrm{~m}$ seine sampling intervals being demarcated. The midpoints of the sampling intervals (O) correspond with positions of seine bags (seine center points). (E) Birdseye diagram of tethering set-up along a single transect. An experimental trial was composed of a group (O) of 6 tethered pinfish, Lagodon rhomboides, deployed at 10,50 , and $110 \mathrm{~m}$ distances from shore along a single transect (i.e. $\mathrm{n}=18$ fish trial $^{-1}$ ). Along the transect, within each distance, pinfish were spaced $10 \mathrm{~m}$ apart. Each transect was visited on different days to enable 2 trials for each transect for a total of 108 tethering experiments. Distance between transects was $\sim 500 \mathrm{~m}$. All 3 transects were adjacent to a continuous band of red mangroves (Rhizophora mangle) whose prop root edge directly borders dense seagrass beds (mostly Thalassia testudium)

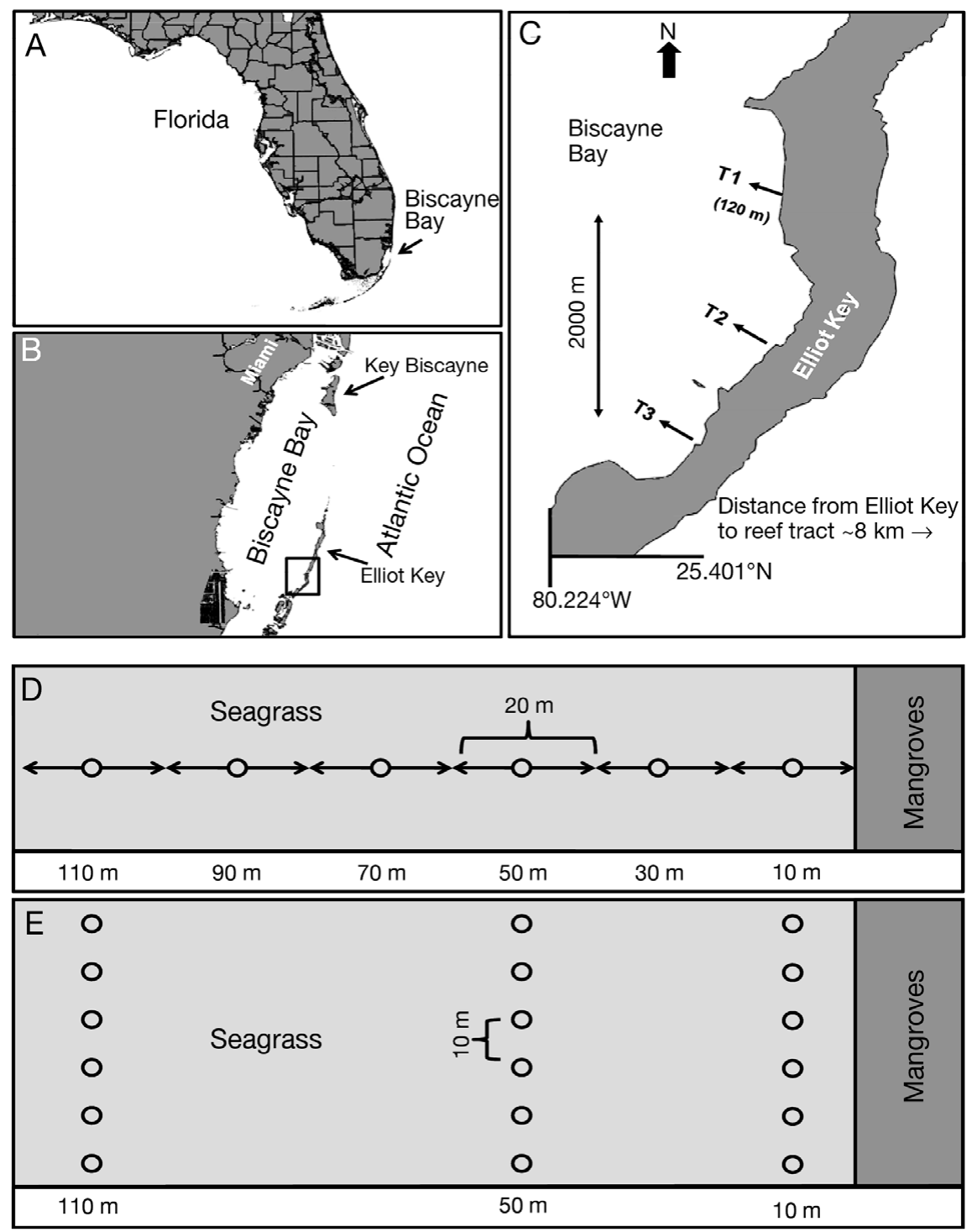


(Rhizophora mangle), where the prop root edge directly borders dense seagrass beds (mostly Thalassia testudium). Sampling activities were focused along three $120 \mathrm{~m}$ long transects that extended perpendicularly from shore (Fig. 1). All 3 transects were adjacent to mangroves that are used as daytime shelter by fishes (Serafy et al. 2003, 2007). Water temperature along these transects ranged between 32.2 to $34.9^{\circ} \mathrm{C}$ and salinity was stable (range: 34 to 39). Across transects, seagrass and macroalgae bottom cover was high (range: 66 to $96 \%$ ) and depths were consistently shallow (range: 72 to $120 \mathrm{~cm}$ ) out to $120 \mathrm{~m}$ from shore (Table 1). Seine net sampling also indicated that the composition and structure of fish communities were very similar among transects (Hammerschlag \& Serafy 2010). Consistency in the above physical and abiotic characteristics among transects (Table 1) allowed us to minimize variation in environmental factors which could confound predator-prey relationships (e.g. Hammerschlag et al. 2006).

Focal fishes. We selected juvenile gray snapper, bluestriped grunt and seabream because (1) these species are among the most easily identified fishes in our location; (2) each is representative of a different trophic guild (seabream-herbivore, bluestriped grunt-crustacean zoobenthivore, gray snappergeneralist zoobenthivore; Hammerschlag et al. 2010b); and (3) two have economic importance in the region's recreational fishery and dive tourism industry (gray snapper and bluestriped grunt). We focused on individuals ranging between 10 and $25 \mathrm{~cm}$ in total length (TL) since this size class represents fishes that are best known to make diel movements among mangroves to seagrass habitats (Rooker \& Dennis 1991, Nagelkerken et al. 2000, Hammerschlag \& Serafy 2010).

To examine the effects of food availability and predation risk on fish habitat use along our transects, we first quantified patterns of fish distribution, food abundance and predation risk.

Fish distribution and food supply. Previous gut content studies of the focal fishes in our study area (Hammerschlag et al. 2010b) revealed that gray snapper fed primarily on small fishes (hardhead silversides Atheri- nomorus stipes; mojarras Eucinostomus spp., rainwater killifish Lucania parva) and crustaceans (pink shrimp Farfantepenaeus duorarum, and caridean shrimp). Bluestriped grunts fed almost exclusively on caridean shrimp, while seabream fed almost exclusively on seagrass (mostly Thalassia testudium) and algae.

Between July to September 2007 (Florida's wet season), we used center-bag seine nets (21.3 m long, $1.8 \mathrm{~m}$ high, $3 \mathrm{~mm}$ mesh) to simultaneously assess distribution and abundance of both focal fish species and their potential invertebrate and fish prey along our transects (Hammerschlag \& Serafy 2010). Sampling occurred every $20 \mathrm{~m}$ along the three $120 \mathrm{~m}$ long transects (Fig. 1D). Seine nets were hauled parallel to shore against the current (or wind, if stronger) and pursed such that a standardized area of $142 \mathrm{~m}^{2}$ was sampled with each haul. At least 2 seine samples were collected simultaneously and the sequence at which each distance was sampled was chosen randomly. We maintained standardized sampling distances by measuring actual distances from shore using demarcated transect tapes. Sampling was conducted in complete darkness, at least $0.5 \mathrm{~h}$ after sunset and within $2.5 \mathrm{~h}$ of low tide. Each transect was visited on different days to facilitate the collection of 3 to 4 seine samples for each transect-distance combination (i.e. 9 to 12 samples per distance). Focal fishes and their food items were collected, counted and measured to the nearest mm TL. Between 100 and 500 ind. of each species were weighed to the nearest $0.01 \mathrm{~g}$ in the laboratory using digital scales to generate length-weight relationships. Because seagrass and algae are the primary food sources of seabream in our study area, we also quantified vegetation cover every $20 \mathrm{~m}$ along the three $120 \mathrm{~m}$ transects by estimating the percent cover of seagrass and algae within $50 \times 50 \mathrm{~cm}$ quadrats (10 quadrats per distance-transect combination). Vegetation height (cm) was also measured within each quadrat, where the measurement point was selected randomly to minimize bias. This sampling method was chosen to be consistent with existing aquatic vegetation monitoring programs in the region (Fourqurean et al. 2001, Browder et al. 2009).

Table 1. Transect-specific means $( \pm 1 \mathrm{SE})$ of abiotic and physical environmental variables measured at the study area in the wet season: water temperature, salinity, vegetation cover, canopy height and depth. Transects were selected based on consistency in environmental conditions. ANCOVA revealed no significant transect-specific differences in relationships between environmental factors and distance from shore (i.e. temperature, $p>0.51$; salinity, $\mathrm{p}>0.51$; cover, $\mathrm{p}>0.15$; height, $\mathrm{p}>0.57$; depth, $\mathrm{p}>0.24$ )

\begin{tabular}{|c|c|c|c|c|c|}
\hline \multirow{2}{*}{ Transects } & & & \multirow{2}{*}{$\begin{array}{l}\text { Environmental variables } \\
\text { Vegetation cover }(\%)\end{array}$} & \multirow[b]{2}{*}{ Canopy height (cm) } & \multirow[b]{2}{*}{ Depth $(\mathrm{cm}$} \\
\hline & Temperature $\left({ }^{\circ} \mathrm{C}\right)$ & Salinity & & & \\
\hline 1 & $31.5 \pm 0.4$ & $36.2 \pm 0.4$ & $91.5 \pm 1.6$ & $32.5 \pm 1.5$ & $91.1 \pm 3.5$ \\
\hline 2 & $32.8 \pm 0.1$ & $36.2 \pm 0.1$ & $93.3 \pm 1.3$ & $26.0 \pm 1.2$ & $89.6 \pm 2.9$ \\
\hline 3 & $32.9 \pm 0.2$ & $37.2 \pm 0.4$ & $83.9 \pm 2.5$ & $28.4 \pm 0.9$ & $110.8 \pm 4.9$ \\
\hline
\end{tabular}


Predator encounter rates. To seasonally correspond with the period of seine sampling from July to September 2008 (wet season), we assessed nocturnal patterns of predator encounter rates along our transects using tethering experiments (Hammerschlag et al. 2010a). Pinfish Lagodon rhomboides were used as bait because individuals in the size range corresponding with the focal fishes were readily available from commercial suppliers and pilot studies demonstrated that pinfish were both physically and behaviorally robust to our tethering process (Hammerschlag et al. 2010a). Specifically, during pilot work, no fish died, exhibited signs of injury, or broke from their tether lines. Furthermore, tethered fish maintained equilibrium and showed no signs of erratic swimming behavior. Pinfish routinely swam from the substrate towards the water's surface, in and out of seagrass, without entanglement.

The tethering technique we employed was modified from Ellis \& Bell (2004). The gear consisted of: (1) a $2 \mathrm{~m}$ long (11.3 kg test) monofilament center line with a $227 \mathrm{~g}$ lead weight attached at one end and a small, plastic float attached to the other; and (2) a $1 \mathrm{~m}$ long (11.3 kg test) monofilament tether line. During deployment, the center line was positioned by pushing the weight into the sediment, allowing the float to sit at the surface. To secure the tether line to a pinfish, one end of the line was threaded through the mouth, out through the operculum, and tied to form a loose loop, just forward of the pinfish's snout. Finally, to secure the tether to the center line, it was connected to the center line using a snap-swivel (0.5 g). This snap-swivel attachment permitted pinfish to move freely in a vertical cylinder, with a $2 \mathrm{~m}$ diameter, from the seagrass to the water surface (Hammerschlag et al. 2010a).

To examine relationships between pinfish removal rates (a proxy for predator encounter rates by our focal species) and proximity to mangroves, tethered pinfish were deployed at distances of 10, 50, and $110 \mathrm{~m}$ from the mangrove shoreline along the 3 transects. An experimental trial was composed of a group of 6 tethered pinfish simultaneously deployed at each of the 3 distances from shore along a single transect (i.e. $\mathrm{n}=18$ fish trial $^{-1}$ along a single transect; Fig. 1E). At each distance, pinfish were spaced $10 \mathrm{~m}$ apart. All tethers were retrieved after $60 \mathrm{~min}$, with absence of the pinfish (or presence of a severed fish or predator on the line) being recorded as a predation event. To correspond with seine sampling, all experiments were conducted in complete darkness from 0.5 to $2.0 \mathrm{~h}$ after sunset and within $2.5 \mathrm{~h}$ of low tide. Each transect was visited on different days to enable 2 trials transect ${ }^{-1}$ (Fig. 1E).

Data analyses. Mean densities of gray snapper, bluestriped grunt and seabream were determined for each transect-distance combination using a deltadistribution mean estimator (Fletcher et al. 2005), which is a measure of fish density (hereafter just density) that separately considers the proportion of samples positive for a given fish species (i.e. frequency of occurrence) and its mean density when present (i.e. concentration). This approach was previously used to examine mangrove fish density patterns in Biscayne Bay (Faunce \& Serafy 2007, Serafy et al. 2007, Faunce \& Serafy 2008). To reveal overall relative fish density-proximity patterns, we calculated relative fish densities at each distance from shore (following Heithaus et al. 2009) by dividing the mean fish density at each distance by the sum of mean fish densities across the $120 \mathrm{~m}$ distance gradient. Relative fish densities were calculated separately for all transects. ANCOVA revealed no significant transect-specific differences in density-distance relationships ( $p>0.05$ for all species), so subsequent relationships between relative fish density and distance (pooled by transect) were evaluated using regression analysis, applying linear and quadratic models.

Food available to foraging fishes was determined by using all food types that were frequently consumed by the focal fishes (i.e. prey items occurring in $>5 \%$ of fishes collected, following Krebs 1998) based on our stomach content analysis (Hammerschlag et al. 2010b). Mean biomass of prey items in each transect-distance combination were used to measure food availability for each of the focal fishes. Prey biomass in each sample was determined from overall catches by applying species-specific length-weight relationships (following Heithaus \& Dill 2002). To reveal overall relative food supply-proximity patterns, we calculated relative food abundance at each distance from shore (following Heithaus et al. 2009) in the same manner as for relative fish density (i.e. mean food biomass per distance divided by the sum of mean food abundances across the distance gradient). Because seabream consumed vegetation (seagrass and macroalgae), we also calculated above-ground vegetation volume (area covered $\times$ height; $\mathrm{m}^{3}$ ) for each quadrat (following Wirsing et al. 2007). Relative vegetation volume was calculated in the same manner for each transect, by dividing mean vegetation volume at each distance from shore by the sum of mean vegetation volume across the $120 \mathrm{~m}$ distance gradient (following Heithaus et al. 2009). Transect differences in biomass-distance relationships were not significant (ANCOVA, p > 0.30 for all species), thus subsequent relationships between relative food abundances and distance (pooled by transect) were evaluated via regression analysis, applying linear and quadratic models.

To test theoretical predictions of the links between food availability, predation risk, and forager abun- 
dance, we calculated the ratio of foragers relative to their food availability (hereafter referred to as 'relative forager densities'; e.g. Heithaus et al. 2007b, Wirsing et al. 2007) by dividing the relative abundance of foragers by the relative food abundance at each distance from shore (following Heithaus et al. 2009). A ratio of 1.0 across all distances indicates that fish habitat use is proportional to food abundance (an ideal free distribution). Values $<1.0$ indicate undermatching of resources (i.e. fewer foragers than predicted by food abundance and presumably higher intake rates per forager), while values $>1.0$ indicate overmatching of food resources (i.e. more foragers than predicted by food abundance and presumably lower intake rates). If foragers were distributed according to an IFD, we would expect 'all distances' from mangroves to have relative forager densities of 1.0, but to deviate from this pattern if other factors (e.g. predation risk) were influencing nocturnal fish distributions. Relationships between relative forager densities and distance were examined using regression analysis.

In cases where fish did not match an IFD, we investigated whether predation risk might be responsible for deviations from model predictions by comparing tether predation losses at each distance from shore using logistic regression on data presented by Hammerschlag et al. (2010a). Predation rate-distance relationships did not differ significantly among transects (ANCOVA, p > 0.40), thus a single relationship between predation rate and distance from shore was calculated following Baker \& Sheaves (2007) and applied along the entire distance gradient for all 3 focal fishes.

To gain insight as to whether fishes were distributed such that they were optimizing energy intake and safety, we calculated a proxy for $\mu / f$ at each distance from shore and compared these values with observed fish distributions. To calculate these estimates of $\mu / f$, we divided the rate of predation loss in tethering experiments by relative food supply (Dahlgren \& Eggleston 2000). While this measure does not take into account density-dependent declines in food intake at a particular distance, it provides insight into the relative risks and gains available to fishes at each distance. Relationships between $\mu / f$ and distance from shore were evaluated using regression analysis.

In addition, we further hypothesized that if fish were responsive to predation risk as well as shifted habitats in a way that minimized the ratio of mortality risk to foraging rate, then we would expect to see $\mu / f$ values correlate with deviations from IFD. In particular, we hypothesized that $\mu / f$ values would be highest where relative forager densities were lowest (i.e. values $<1.0$ ) and vice versa. All statistical analyses were performed using SAS (1990) software.

\section{RESULTS}

Sixty-two seine samples yielded 315 specimens of juvenile gray snapper $(\mathrm{n}=58)$, bluestriped grunt $(\mathrm{n}=$ 128) and seabream $(n=129)$, ranging in size from $10-25 \mathrm{~cm}$ TL for gray snapper and bluestriped grunt and $10-20 \mathrm{~cm}$ TL for seabream. Gray snapper and seabream relative densities significantly increased with increasing distance from shore $\left(\mathrm{R}^{2}=0.34, \mathrm{p}<0.01\right.$, Fig. $2 \mathrm{~A}_{;} \mathrm{R}^{2}=$ 0.59 , p $<0.01$, Fig. 2E, respectively). In contrast, bluestriped grunt showed no significant change in density along the distance gradient (Fig. 2C). Detailed densitydistance relationships of the focal fishes can be found in a complementary paper (Hammerschlag \& Serafy 2010); however, mean fish density-distance patterns are also provided in Table 2, which mirror relative fish densitydistance distributions (Fig. 2).

Seining also yielded 5609 potential food items of gray snapper and bluestriped grunt. This included caridean shrimp for bluestriped grunt (their primary prey) and mojarra, rainwater killifish, hardhead silverside, pink shrimp and caridean shrimp for gray snapper. Mean biomass and lengths of different fish food items across the distance gradient are provided in Table 3. Relative prey availability for gray snapper showed no significant change along the distance gradient, although biomass tended to be higher closer to shore (Fig. 2B, Table 3A). In contrast, bluestriped grunt prey availability followed a parabolic distribution pattern along the distance gradient $\left(\mathrm{R}^{2}=0.54, \mathrm{p}<0.01\right.$, Fig. 2D; Table 3A), with lowest values at intermediate distances. A total of 178 quadrats provided estimates of above-ground vegetation volume (seabream food) along the distance gradient. Seabream food supply significantly decreased with increasing distance from shore $\left(R^{2}=0.51, p<0.01\right.$, Fig. 2F; Table 3B).

Logistic regression based on data from 108 tethered fish indicated a negative correlation between predation losses and distance from shore $(\mathrm{p}<0.01$, concordance index $\mathrm{c}=0.65$; Fig. 3), with predation loss ranging from $70 \%$ nearest the mangroves $(10 \mathrm{~m})$ to $35 \%$ at the furthest distance from shore $(110 \mathrm{~m})$. This relationship was subsequently used to represent predation pressure along the entire distance gradient for all 3 focal fishes.

Gray snapper distribution relative to its food supply (i.e. ratio of foragers relative to their food availability) significantly increased with increasing distance from shore $\left(R^{2}=0.46, p<0.01\right.$, Fig. $\left.4 A\right)$. This indicates undermatching of food supply near shore (0 to $40 \mathrm{~m}$ ) and overmatching of food abundance at distances of 80 to $120 \mathrm{~m}$. Bluestriped grunt habitat use relative to their food abundance followed a parabolic distribution pattern $\left(R^{2}=0.31, p<0.02\right.$, Fig. $\left.4 C\right)$. This suggests approximate matching of food abundance near shore $(0$ to 

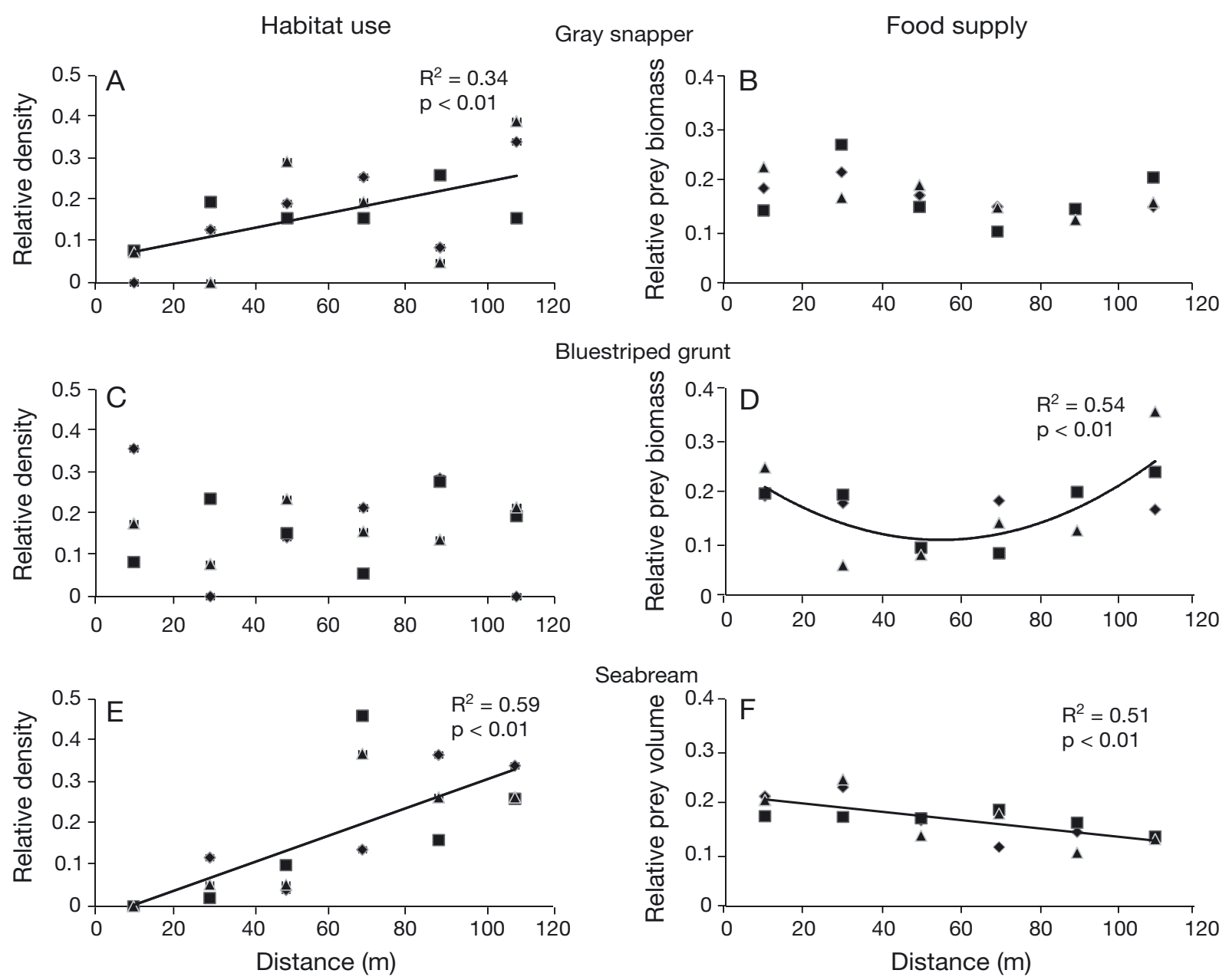

Fig. 2. Lutjanus griseus, Haemulon sciurus and Archosargus rhomboidalis. Relative density-distance patterns of juvenile gray snapper, bluestriped grunt, seabream $(\mathrm{A}, \mathrm{C}, \mathrm{E})$ and their food supply $(\mathrm{B}, \mathrm{D}, \mathrm{F})$. Values are transect-specific relative densities for fishes and biomass for prey items. Symbol shapes represent different transects. Solid lines and associated $\mathrm{R}^{2}$ values indicate significant distance patterns $(\mathrm{p}<0.05)$

$40 \mathrm{~m}$ ), overmatching between 40 to $80 \mathrm{~m}$ from shore, and slightly undermatching of food supply furthest from shore (80 to $120 \mathrm{~m}$ ). Seabream distribution relative to their food supply significantly increased with increasing distance from shore $\left(R^{2}=0.64, p<0.01\right.$, Fig. 4E), indicating undermatching of food supply near shore (0 to $40 \mathrm{~m})$, and overmatching at further distances (60 to $120 \mathrm{~m}$ ).

For gray snapper and seabream, $\mu / f$ significantly decreased with increasing distance from shore $\left(R^{2}=0.27\right.$, $\mathrm{p}<0.03$, Fig. 4B; $R^{2}=0.97, \mathrm{p}<0.01$, Fig. 4F, respectively) For bluestriped grunt, $\mu / f$ followed a parabolic pattern

Table 2. Lutjanus griseus, Haemulon sciurus and Archosargus rhomboidalis. Mean nocturnal densities $( \pm 1$ SE) of focal fishes per seine haul $\left(142 \mathrm{~m}^{2}\right)$ at each distance in our study area. ANCOVA revealed no significant transect-specific differences in fish density-distance relationships (i.e. gray snapper, $\mathrm{p}>0.61$; bluestriped grunt, $\mathrm{p}>0.62$; seabream, $\mathrm{p}>0.49$ ). Detailed densitydistance relationships of the focal fishes can be found in Hammerschlag \& Serafy (2010); however, mean fish density-distance patterns mirror relative fish density-distance distributions displayed in Fig. 2. See text for details

\begin{tabular}{|c|c|c|c|c|c|c|}
\hline \multirow{2}{*}{ Taxon } & \multicolumn{6}{|c|}{ Distance $(\mathrm{m})$} \\
\hline & 10 & 30 & 50 & 70 & 90 & 110 \\
\hline Gray snapper & $0.3 \pm 0.2$ & $0.6 \pm 0.2$ & $1.2 \pm 0.3$ & $1.1 \pm 0.2$ & $0.8 \pm 0.2$ & $1.6 \pm 0.3$ \\
\hline Bluestriped grunt & $1.7 \pm 0.5$ & $1.9 \pm 0.7$ & $2.2 \pm 0.7$ & $1.4 \pm 0.4$ & $2.8 \pm 0.7$ & $2.5 \pm 0.5$ \\
\hline Seabream & 0.0 & $0.7 \pm 0.6$ & $0.7 \pm 0.4$ & $3.4 \pm 1.2$ & $2.8 \pm 1.7$ & $3.1 \pm 1.2$ \\
\hline
\end{tabular}


Table 3. Lutjanus griseus, Haemulon sciurus and Archosargus rhomboidalis. (A) Mean abundance per seine haul (142 $\mathrm{m}^{2}$; measured as biomass of animals in $\mathrm{g}$ or \% cover of plants), and (B) length of different fish food items across the distance gradient. In (B), vegetation values are mean canopy height and mean above-ground volume $\left(\mathrm{m}^{3}\right)$. TL: total length $(\mathrm{cm})$. Shrimp length measurements were post-orbital lengths. All caridean shrimp measured were between 0.2 to $0.5 \mathrm{~cm}$. In our study area, gray snapper feed on hardhead silversides, rainwater killifish, pink shrimp, and caridean shrimp. Bluestriped grunts feed almost exclusively on caridean shrimp, while seabream feed almost exclusively on vegetation, composed of seagrass (mostly Thalassia testudium) and algae (Hammerschlag et al. 2010b). All values are means $\pm 1 \mathrm{SE}$

\begin{tabular}{|c|c|c|c|c|c|c|}
\hline \multirow[t]{2}{*}{ Taxon } & \multicolumn{6}{|c|}{ Distance $(\mathrm{m})$} \\
\hline & 10 & 30 & 50 & 70 & 90 & 110 \\
\hline \multicolumn{7}{|l|}{ (A) Food abundance vs. distance } \\
\hline Hardhead silversides (biomass) & $90.1 \pm 17.3$ & $107.1 \pm 23.4$ & $71.8 \pm 18.5$ & $57.9 \pm 10.8$ & $60.3 \pm 11.7$ & $81.1 \pm 12.9$ \\
\hline Mojarras (biomass) & $58.6 \pm 17.4$ & $102.5 \pm 26.1$ & $79.9 \pm 18.7$ & $45.3 \pm 7.8$ & $53.1 \pm 12.2$ & $80.8 \pm 31.0$ \\
\hline Rainwater killifish (biomass) & $3.0 \pm 1.5$ & $1.2 \pm 0.4$ & $1.3 \pm 0.9$ & $1.1 \pm 0.4$ & $1.2 \pm 0.6$ & $2.0 \pm 0.7$ \\
\hline Pink shrimp (biomass) & $16.9 \pm 6.6$ & $17.9 \pm 3.7$ & $12.0 \pm 3.9$ & $20.3 \pm 5.6$ & $19.3 \pm 9.6$ & $15.2 \pm 3.6$ \\
\hline Caridean shrimp (biomass) & $4.3 \pm 1.4$ & $2.9 \pm 1.4$ & $1.8 \pm 0.6$ & $2.4 \pm 0.9$ & $3.7 \pm 1.1$ & $6.6 \pm 2.3$ \\
\hline Seagrass (\% cover) & $87.8 \pm 2.4$ & $87.9 \pm 2.1$ & $85.3 \pm 3.0$ & $80.1 \pm 2.9$ & $73.6 \pm 4.0$ & $75.0 \pm 3.0$ \\
\hline Algae (\% cover) & $8.4 \pm 1.6$ & $6.4 \pm 1.5$ & $4.5 \pm 0.9$ & $10.6 \pm 2.2$ & $9.7 \pm 1.2$ & $8.2 \pm 1.0$ \\
\hline \multicolumn{7}{|c|}{ (B) Food length $(\mathrm{cm}) \&$ vegetation volume vs. distance } \\
\hline Hardhead silversides (TL) & $4.6 \pm 0.9$ & $4.5 \pm 0.9$ & $4.4 \pm 0.9$ & $4.4 \pm 0.9$ & $4.2 \pm 0.9$ & $4.4 \pm 0.9$ \\
\hline Mojarras (TL) & $4.7 \pm 1.7$ & $4.8 \pm 1.7$ & $4.9 \pm 1.7$ & $4.5 \pm 1.5$ & $4.5 \pm 1.7$ & $4.3 \pm 1.8$ \\
\hline Rainwater killifish (TL) & $2.1 \pm 0.3$ & $2.1 \pm 0.4$ & $2.1 \pm 0.3$ & $2.1 \pm 0.3$ & $2.1 \pm 0.3$ & $2.1 \pm 0.3$ \\
\hline Pink shrimp (TL) & $1.5 \pm 0.6$ & $1.6 \pm 0.5$ & $1.4 \pm 0.5$ & $1.7 \pm 0.6$ & $1.6 \pm 0.6$ & $1.4 \pm 0.6$ \\
\hline Caridean shrimp (TL) & $<0.6$ & $<0.6$ & $<0.6$ & $<0.6$ & $<0.6$ & $<0.6$ \\
\hline Vegetation height (TL) & $32.5 \pm 1.7$ & $36.2 \pm 2.3$ & $27.4 \pm 1.0$ & $27.7 \pm 1.6$ & $25.0 \pm 1.3$ & $24.8 \pm 1.3$ \\
\hline Vegetation volume $\left(\mathrm{m}^{3}\right)$ & $0.3 \pm 0.1$ & $0.4 \pm 0.1$ & $0.3 \pm 0.1$ & $0.3 \pm 0.1$ & $0.2 \pm 0.1$ & $0.2 \pm 0.1$ \\
\hline
\end{tabular}

with distance $\left(\mathrm{R}^{2}=0.51, \mathrm{p}<0.02\right.$, Fig. 4D), with highest values tending to be closer to shore ( 0 to $80 \mathrm{~m})$ and lowest values tending to be furthest from shore (80 to $120 \mathrm{~m})$.

\section{DISCUSSION}

If the focal fishes were distributed across the distance gradient in proportion to their food supply (i.e. an ideal free distribution), relative forager densities (i.e. the ratio of foragers relative to their food availability) at all distances from mangroves should have been

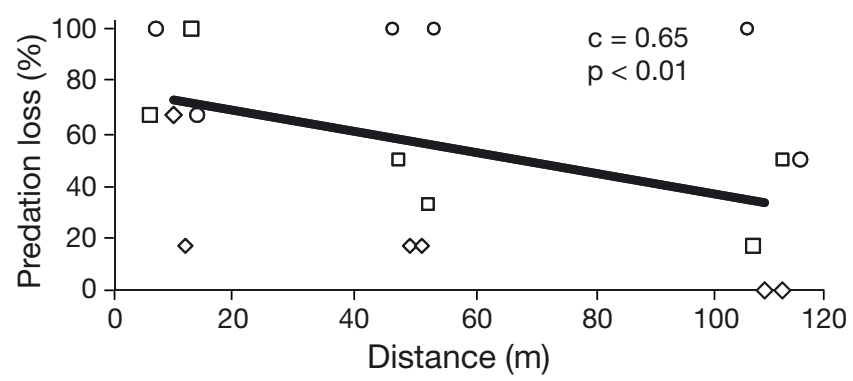

Fig. 3. Lagodon rhomboidalis. Significant fit of logistic regression relating predation losses of tethered pinfish against distance from shore $(p<0.01)$. c: concordance index. Symbols represent raw transect-specific proportions of tethered fish removal at each sampling distance. Data were jittered to reveal overlapping predation values $\sim 1.0$; however, this was not the case for any of the focal fishes along the transects. Thus, all 3 species do not appear to concentrate their foraging in a way that solely maximizes energy intake rates. Stomach content analysis of our fishes suggest that they were foraging during our sampling period (Hammerschlag et al. 2010b); however, it is worth considering that if some species were in transit to or from the mangroves, our measure of relative forager densities would have tended to overestimate the abundance of fishes foraging nearest the mangroves. Thus, if there was a true IFD in such a case, we would expect relative forager densities to be slightly $>1.0$ nearest the shore; however, the opposite pattern was found for all 3 species.

Both gray snapper and seabream distributions were generally consistent with predictions of a food-risk tradeoff. They undermatched food resources near shore and exhibited the highest densities in the safest habitats furthest from the mangroves. Both species avoided foraging in high-risk, but productive areas near mangroves. This pattern suggests that seabream and gray snapper travel far from shore to forage at a reduced risk of predation. Consistent with our hypotheses for both species, $\mu / f$ values generally correlated with deviations from IFD (i.e. $\mu / f$ values were highest where foragers undermatched their prey and vice versa). However, there was less consistency in this pattern across sites for gray snapper at the furthest distances from shore. 

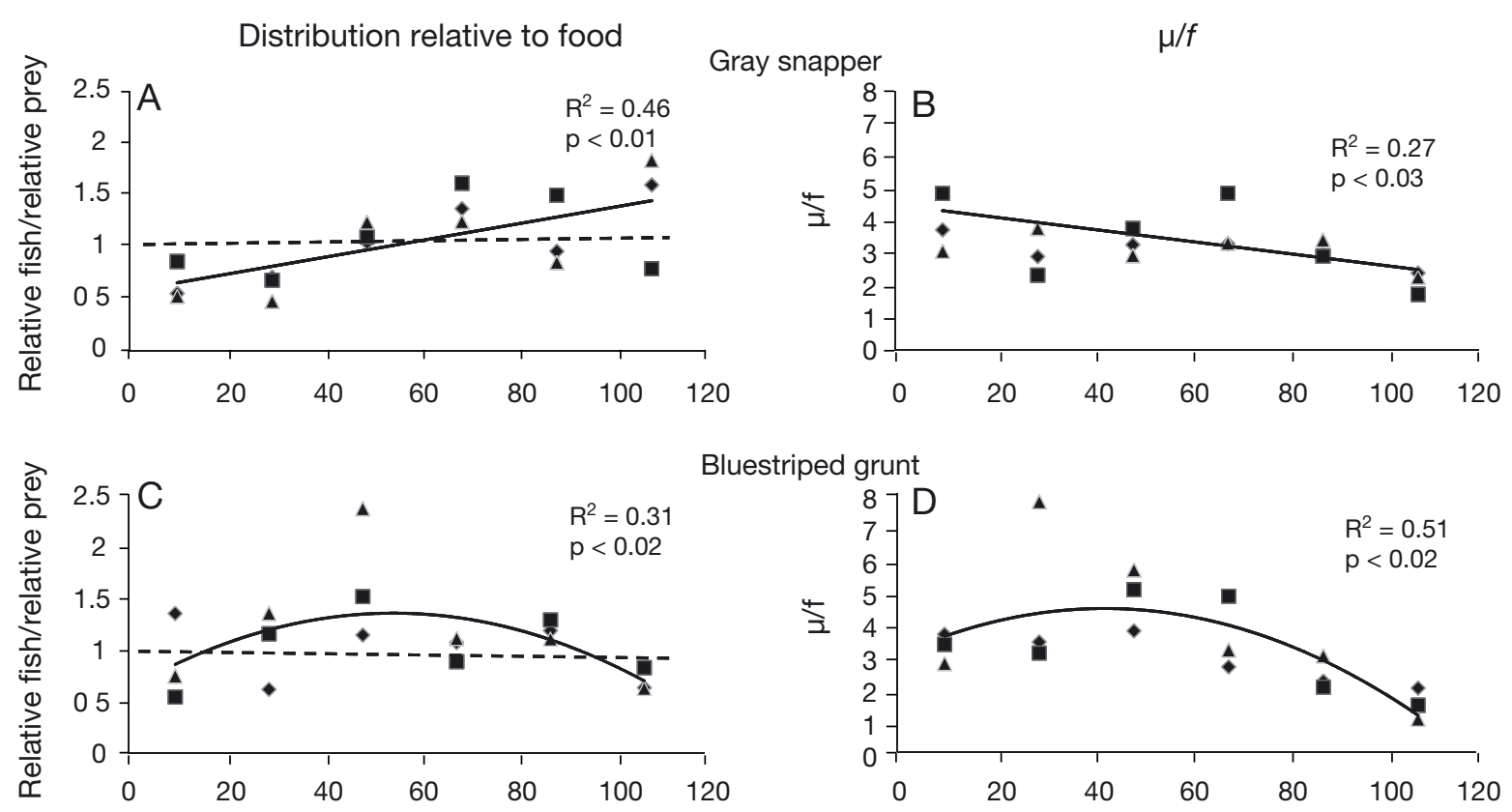

Bluestriped grunt
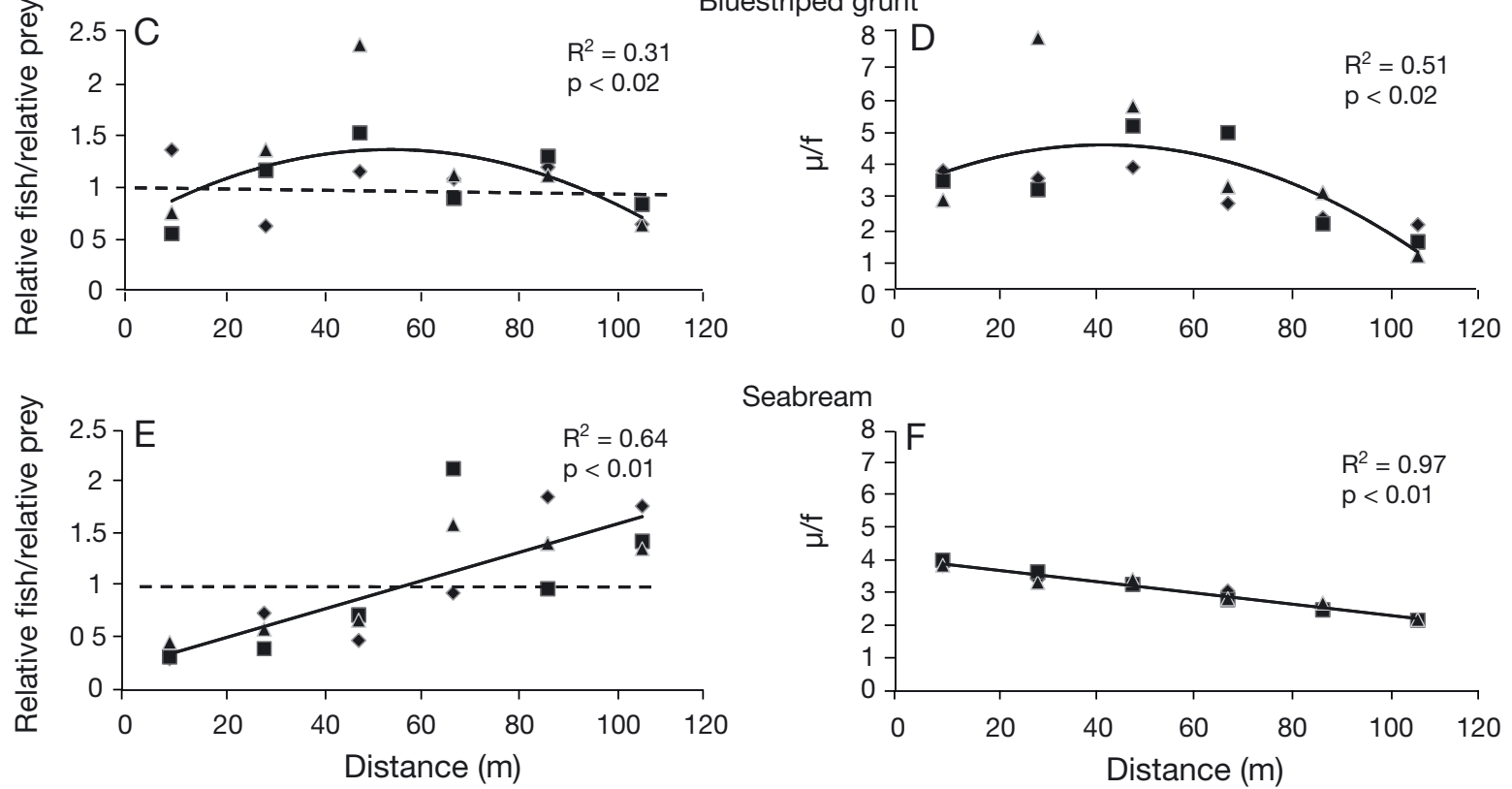

Seabream

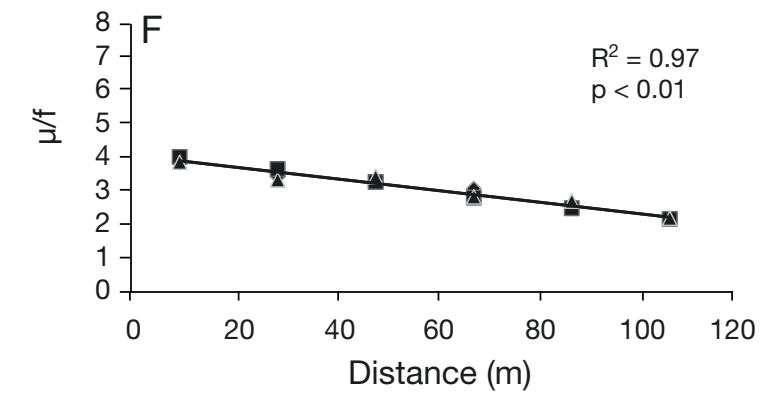

Fig. 4. Lutjanus griseus, Haemulon sciurus and Archosargus rhomboidalis. Effects of food availability and predation risk on habitat use by gray snapper $(A, B)$, bluestriped grunt $(C, D)$ and seabream $(E, F)$. Fish distributions are plotted relative to food availability (relative forager densities) along the $120 \mathrm{~m}$ distance gradient (A,C,E). A ratio of 1.0 at different distances (dashed lines) indicates that fish habitat use is proportional to food abundance (an ideal free distribution). Values of predation risk $(\mu)$ were divided by food supply $(f)$ along the $120 \mathrm{~m}$ distance gradient $(B, D, F)$. Solid lines and associated $R^{2}$ values indicate significant distance patterns $(\mathrm{p}<0.05)$

In contrast to gray snapper and seabream, bluestriped grunt did not appear to avoid foraging nearest the mangroves, although relative abundances were below that predicted by food abundance. Moreover, bluestriped grunt deviations from IFD along the distance gradient were not consistent with $\mu / f$ predictions or our hypotheses relative to IFD deviations. Perhaps schooling by grunts (Hobson 1965) or other anti-predator tactics or adaptations (e.g. crypsis, vigilance) allow them to compensate for higher predator encounter rates near shore.

Deviations from our predictions could be due to our proxies for both $\mu$ and $f$. First, we used removal rates of tethered pinfish to estimate encounter rates with predators. It is possible that predator encounter rates would be different for each of our focal species. This possibility, however, is unlikely because pinfish, sea- bream, gray snapper and bluestriped grunt occupy the same habitat, have similar body forms, are characterized by similar length-frequency distributions within the same study area, and share common predators (de Sylva 1963, Starck \& Schroeder 1970, Castro 2000, Newman 2003). Moreover, gillnet catch rates of lemon sharks (Negaprion brevirostris, a major predator of the focal fishes; Newman 2003) in our study area are highest closest to shore (Hammerschlag et al. 2010a), corresponding with our tether removal rates of pinfish. Additionally, tracking studies from nearby sites indicate that lemon sharks focus nocturnal search efforts near the mangrove shoreline (Morrissey \& Gruber 1993, Franks 2007). In fact, crossing ecotones between refuges and feeding patches should be risky for foragers because the concentration of individuals in refuges and the predictability of their movements 
attract predators. Therefore, it is highly likely that the propensity of our focal species to undermatch resources near shore is indeed driven by predator avoidance. However, although there is no reason to believe that tethering results would be different for all focal species, it is possible and further research is needed to validate this. Deviations from predictions at greater distances from shore may be due to a number of sources of error. For $\mu$, our proxy only measures predator encounter rates, whereas predation risk is the product of both the probability of encountering a predator and the probability of death given the encounter (Hugie \& Dill 1994). Our proxy for $\mu$ does not account for possible inter-specific differences in the probability of escape given an encounter with predators, which could result from differences in grouping or escape tactics (e.g. Martin et al. 2005, Wirsing et al. 2010; see below). Also, we could not assess the total time spent being exposed to predators, which may vary with excursion distance and, therefore, could result in higher total exposure to predators than our proxy of $\mu$ would suggest. Foraging considerations affecting our measure of $f$ may also cause deviations from our predictions. Animals are predicted to optimize energy intake rates, which do not necessarily correlate with standing stocks of prey for several reasons including prey anti-predatory behaviors, differential prey selectivity by the fishes for particular food types, or interference competition (e.g. Comins \& Hassell 1979, Tregenza 1995, van der Meer \& Ens 1997). At further distances from shore in our study, food resources may begin to become depleted or interference competition likely increases (Sutherland et al. 1988, Sutherland \& Parker 1999), as more fishes begin to forage there. Although tethering and seine studies were conducted during the wet seasons of alternate years, we do not believe there were any significant year effects for 2 reasons. First, seine data from the wet season of 2007 and the dry season of 2008 both reveal similar density-distance patterns of the focal fishes (Hammerschlag \& Serafy 2010). Second, gillnet data from the wet season of 2007 (Hammerschlag et al. 2010a) along our transects mirrors the tethering data from the wet season of 2008 (both indicating highest predator encounter rates nearest the shore).

It is worth considering that although we found predator encounter rates to be highest at our closest tethering locations $(10 \mathrm{~m})$, predation risk may be relatively low immediately adjacent to the mangrove edge or under the prop roots. Indeed, the use of mangroves as a refuge during the day is well-known (Robertson \& Blaber 1992, Laegdsgaard \& Johnson 1995, 2001, Serafy et al. 2003). While fish encountering predators very close to mangroves would have a reasonable chance of escaping back to the prop roots, such escape is much less likely by the time fish have moved $10 \mathrm{~m}$ offshore, especially at night when a fish's ability to detect patrolling predators may be hindered. Acoustic tracking of gray snapper supports our notion that they avoid areas near mangroves despite high food availability. At sunset, snapper migrate rapidly out of the mangroves in a synchronized fashion and do not forage in seagrass nearest the mangroves (Luo et al. 2009). For both gray snapper and seabream, selecting offshore foraging locations represents an energetic cost since their food supply is high near the mangroves.

The present study is the first to investigate the influences of food availability and predation risk on nocturnal fish habitat use patterns along a continuous mangrove-seagrass distance gradient. This is also one of the first studies to use behavioral optimization theory to develop testable predictions about the behavior of fish in response to food or predation risk in these systems (e.g. Dahlgren \& Eggleston 2000). However, we caution against broad generalizations based on our study results due to low replication in both space and time. Our results indicate that while some species (e.g. seabream, an herbivore, and gray snapper, a generalist zoobenthivore) appeared to trade off food for safety and foraged away from the mangrove-seagrass ecotone, bluestriped grunt (a crustacean zoobenthivore) did not match theoretical expectations, and foraged randomly across the distance gradient despite habitat spatial variation in food supply and predation risk.

Individual forager responses to variation in predation risk and food availability are not necessarily straightforward. Species may manage risk by employing a variety of complementary behaviors besides habitat shifts (e.g. use of apprehension or vigilance; Brown 1999, Brown \& Kotler 2004, Wirsing et al. 2008). However, food-safety tradeoffs are ubiquitous, and it is likely that fishes in our system are using a variety of avoidance behaviors like schooling, cryptic coloration and vigilance to optimize energy gain and safety from predators (e.g. Hobson 1965, Sogard 1992). Thus, we recommend that future studies investigate a diversity of predator avoidance tactics simultaneously to further elucidate the role of predation risk in shaping distribution patterns of fishes along the seagrass-mangrove ecotone. This work contributes to a growing understanding of the nursery function of mangrove-seagrass systems; however, greater consideration of the combined role of food supply and predation risk in nursery function dynamics is clearly warranted (Adams et al. 2006, Nagelkerken et al. 2008).

Acknowledgements. Funding support for this work was primarily provided by the Herbert W. Hoover Foundation, the Batchelor Foundation Inc, NOAA Living Marine Resources Cooperative Science Center, National Park Service (Biscayne 
National Park - BNP), the SeaStar Foundation, Save the Blue, YSI Inc., the Rosenstiel School of Marine and Atmospheric Science and the University of Miami's South Florida Student Shark Program (SFSSP), now the RJ Dunlap Marine Conservation Program. As part of the educational component of this project, several hundreds of high school and undergraduate students were involved in field data collection, laboratory processing and data organization. We thank all SFSSP volunteers, primarily D. Ovando, A. Morgan, A. Disilvestro, A. Matulik, D. Lazarre, A. Krajca, L. Winn, E. Overstreet, L. Rock, A. Griefen, M. Fast, L. Glade, K. Titley, J. Ross, C. Antal, X. Serrano, D. Washington and J. Allen for technical support, and especially thank D. Lirman, L. Brand, T. Kellison, G. Thomas, D. Die, C. M. Hammerschlag, L. Yeager, H. Luria, S. Spielman, L. Hoover and R. Mann. We also thank G. Myers, M. Giganti, M. Lewis, E. Alvear, R. Curry and H. M. Tritt for logistical support; J. Luo, G. Harvey and S. Stock for providing underwater cameras for this research; and the anonymous reviewers whose comments significantly helped strengthen this paper. This work was conducted under BNP Permit \# BISC-2008-SCI-0003, BISC-2008-SCI-0005 and the University of Miami Institutional Animal Care and Use Committee (IACUC) Protocol \# 05-244 renewal02.

\section{LITERATURE CITED}

Abrahams MV, Dill LM (1989) A determination of the energetic equivalence of the risk of predation. Ecology 70: 999-1007

Adams AJ, Dahlgren CP, Kellison GT, Kendall MS and others (2006) Nursery function of tropical back-reef systems. Mar Ecol Prog Ser 318:287-301

Baker R, Sheaves M (2007) Shallow-water refuge paradigm: conflicting evidence from tethering experiments in a tropical estuary. Mar Ecol Prog Ser 349:13-22

Browder JA, Liehr GA, Johnson D, Buck E, Jackson TJ (2009) Epifaunal communities of mainland nearshore South Biscayne Bay. Annual report to the U.S. Army Corps of Engineers and the RECOVER Group of the Comprehensive Everglades Restoration Program, SE MAP Project 3.2.3.5 \& 3.2.4.7. USACE WO 9:167

Brown JS (1988) Patch use as an indicator of habitat preference, predation risk, and competition. Behav Ecol Sociobiol 22:37-47

Brown JS (1992) Patch use under predation risk. 1. Models and predictions. Ann Zool Fenn 29:301-309

Brown JS (1999) Vigilance, patch use and habitat selection: foraging under predation risk. Evol Ecol Res 1:49-71

Brown JS, Kotler BP (2004) Hazardous duty pay and the foraging cost of predation. Ecol Lett 7:999-1014

Bystrom P, Persson L, Wahlstrom E, Westman E (2003) Sizeand density-dependent habitat use in predators: consequences for habitat shifts in young fish. J Anim Ecol 72: $156-168$

Castro JI (2000) The biology of the nurse shark, Ginglymostoma cirratum, off the Florida east coast and the Bahama Islands. Environ Biol Fishes 58:1-22

Chittaro PM, Usseglio P, Sale P (2005) Variation in fish density, assemblage composition and relative rates of predation among mangrove, seagrass and coral reef habitats. Environ Biol Fishes 72:175-187

> Comins HN, Hassell MP (1979) The dynamics of optimally foraging predators and parasitoids. J Anim Ecol 48:335-351

Creel S, Christianson D (2008) Relationships between direct predation and risk effects. Trends Ecol Evol 23:194-201

Cresswell W (1994) Age-dependent choice of redshank
(Tringa totanus) feeding location: profitability or risk? J Anim Ecol 63:589-600

Dahlgren CP, Eggleston DB (2000) Ecological processes underlying ontogenetic habitat shifts in a coral reef fish. Ecology 81:2227-2240

de Sylva D (1963) Systematics and life history of the great barracuda Sphyraena barracuda (Walbaum), Vol 1. Institute of Marine Science, University of Miami, Coral Gables, FL > Dorenbosch M, Grol MGG, de Groene A, Van der Velde G, Nagelkerken I (2009) Piscivore assemblages and predation pressure affect relative safety of some back-reef habitats for juvenile fish in a Caribbean bay. Mar Ecol Prog Ser 379:181-196

> Dupuch A, Dill LM, Magnan P (2009) Testing the effects of resource distribution and inherent habitat riskiness on simultaneous habitat selection by predators and prey. Anim Behav 78:705-713

- Ellis WL, Bell SS (2004) Conditional use of mangrove habitats by fishes: depth as a cue to avoid predators. Estuaries 27: 966-976

Faunce $\mathrm{CH}$, Serafy JE (2007) Nearshore habitat use by gray snapper (Lutjanus griseus) and bluestriped grunt (Haemulon sciurus): environmental gradients and ontogenetic shifts. Bull Mar Sci 80:473-495

> Faunce CH, Serafy JE (2008) Growth and secondary production of an eventual reef fish during mangrove residency. Estuar Coast Shelf Sci 79:93-100

Fletcher D, MacKenzie D, Villouta E (2005) Modelling skewed data with many zeros: a simple approach combining ordinary and logistic regression. Environ Ecol Stat 12: 45-54

Fourqurean JW, Durako MJ, Hall MO, Hefty LN (2001) Seagrass distribution in south Florida: a multi-agency coordinated monitoring program. CRC Press, Boca Raton, FL

Franks B (2007) The spatial ecology and resource selection of juvenile lemon sharks (Negaprion brevirostris) in their primary nursery areas. PhD dissertation, Drexel University, Philadelphia, PA

Fretwell SD, Lucas HL (1970) On territorial behavior and other factors influencing habitat distribution in birds. I. Theoretical development. Acta Biotheor 19:16-36

Frid A, Dill LM, Thorne RE, Blundell GM (2007) Inferring prey perception of relative danger in large-scale marine systems. Evol Ecol Res 9:635-649

- Frid A, Baker GG, Dill LM (2008) Do shark declines create fear-released systems? Oikos 117:191-201

> Gilliam JF, Fraser DF (1987) Habitat selection under predation hazard: test of a model with foraging minnows. Ecology 68:1856-1862

Grand TC, Dill LM (1997) The energetic equivalence of cover to juvenile coho salmon (Oncorhynchus kisutch): ideal free distribution theory applied. Behav Ecol 8:437-447

Grol MGG, Dorenbosch M, Kokkelmans EMG, Nagelkerken I (2008) Mangroves and seagrass beds do not enhance growth of early juveniles of a coral reef fish. Mar Ecol Prog Ser 366:137-146

> Hammerschlag N, Serafy J (2010) Nocturnal fish utilization of a subtropical mangrove-seagrass ecotone. PSZN I: Mar Ecol 31:364-374

Hammerschlag N, Martin RA, Fallows C (2006) Effects of environmental conditions on predator-prey interactions between white sharks (Carcharodon carcharias) and Cape fur seals (Arctocephalus pusillus pusillus) at Seal Island, South Africa. Environ Biol Fishes 76:341-350

Hammerschlag N, Morgan AB, Serafy JE (2010a) Relative predation risk for fishes utilizing a subtropical mangrove-seagrass ecotone. Mar Ecol Prog Ser 401:259-267 
Hammerschlag N, Ovando D, Serafy JE (2010b) Seasonal diet and feeding habits of juvenile fishes foraging along a subtropical marine ecotone. Aquat Biol 9:279-290

Heithaus MR, Dill LM (2002) Food availability and tiger shark predation risk influence bottlenose dolphin habitat use. Ecology 83:480-491

Heithaus MR, Frid A, Wirsing AJ, Dill LM and others (2007a) State-dependent risk-taking by green sea turtles mediates top-down effects of tiger shark intimidation in a marine ecosystem. J Anim Ecol 76:837-844

Heithaus MR, Wirsing AJ, Frid A, Dill LM (2007b) Behavioral indicators in marine conservation: lessons from a pristine seagrass ecosystem. Isr J Ecol Evol 53:355-370

> Heithaus MR, Frid A, Wirsing AJ, Worm B (2008) Predicting ecological consequences of marine top predator declines. Trends Ecol Evol 23:202-210

Heithaus MR, Wirsing AJ, Burkholder D, Thomson J, Dill LM (2009) Towards a predictive framework for predator risk effects: the interaction of landscape features and prey escape tactics. J Anim Ecol 78:556-562

> Hernandez L, Laundre JW (2005) Foraging in the 'landscape of fear' and its implications for habitat use and diet quality of elk Cervus elaphus and bison Bison bison. Wildl Biol $11: 215-220$

> Hobson ES (1965) Diurnal-nocturnal activity of some inshore fishes in the Gulf of California. Copeia 1965:291-302

Houston AI, McNamara JM, Hutchinson JMC (1993) General results concerning the trade-off between gaining energy and avoiding predation. Philos Trans R Soc Lond B 341: 375-397

Hugie DM, Dill LM (1994) Fish and game: a game theoretic approach to habitat selection by predators and prey. J Fish Biol 45:151-169

Kieckbusch DK, Koch MS, Serafy JE, Anderson WT (2004) Trophic linkages among primary producers and consumers in fringing mangroves of subtropical lagoons. Bull Mar Sci 74:271-285

Krebs CJ (1998) Ecological methodology. Benjamin Cummings, Menlo Park, CA

Krebs JR, Davies NB (1984) Behavioural ecology: an evolutionary approach. Sinauer Associates, Sunderland, MA

Laegdsgaard P, Johnson CR (1995) Mangrove habitats as nurseries: unique assemblages of juvenile fish in subtropical mangroves in Eastern Australia. Mar Ecol Prog Ser 126:67-81

Laegdsgaard P, Johnson C (2001) Why do juvenile fish utilise mangrove habitats? J Exp Mar Biol Ecol 257:229-253

Laundre JW, Hernandez L, Altendorf KB (2001) Wolves, elk, and bison: reestablishing the 'landscape of fear' in Yellowstone National Park, USA. Can J Zool 79:1401-1409

Lima SL (1998) Stress and decision making under the risk of predation: recent developments from behavioral, reproductive, and ecological perspectives. In: Moller AP, Milinski M, Slater PJB (eds) Stress and behavior, Vol 27. Academic Press, San Diego, CA, p 215-290

Lima SL, Dill LM (1990) Behavioral decisions made under the risk of predation: a review and prospectus. Can J Zool 68:619-640

Luo J, Serafy JE, Sponaugle S, Teare PB, Kieckbusch D (2009) Diel and seasonal movement of gray snapper (Lutjanus griseus) among subtropical seagrass, mangrove and coral reef habitats. Mar Ecol Prog Ser 380:255-269

- Martin RA, Hammerschlag N, Collier RS, Fallows C (2005) Predatory behaviour of white sharks (Carcharodon carcharias) at Seal Island, South Africa. J Mar Biol Assoc UK 85:1121-1135

Mattila J, Chaplin G, Eilers MR, Heck KL, O'Neal JP, Valen- tine JF (1999) Spatial and diurnal distribution of invertebrate and fish fauna of a Zostera marina bed and nearby unvegetated sediments in Damariscotta River, Maine (USA). J Sea Res 41:321-332

McNamara JM, Houston AI (1987) Starvation and predation as factors limiting population size. Ecology 68:1515-1519

Morris DW (2003) Toward an ecological synthesis: a case for habitat selection. Oecologia 136:1-13

> Morrissey JF, Gruber SH (1993) Home range of juvenile lemon sharks, Negaprion brevirostris. Copeia 1993: 425-434

> Nagelkerken I, van der Velde G (2004a) Are Caribbean mangroves important feeding grounds for juvenile reef fish from adjacent seagrass beds? Mar Ecol Prog Ser 274: $143-151$

> Nagelkerken I, van der Velde G (2004b) Relative importance of interlinked mangroves and seagrass beds as feeding habitats for juvenile reef fish on a Caribbean island. Mar Ecol Prog Ser 274:153-159

> Nagelkerken I, Dorenbosch M, Verberk W, de la Moriniere EC, van der Velde G (2000) Day-night shifts of fishes between shallow-water biotopes of a Caribbean bay, with emphasis on the nocturnal feeding of Haemulidae and Lutjanidae. Mar Ecol Prog Ser 194:55-64

Nagelkerken I, Blaber SJM, Bouillon S, Green P and others (2008) The habitat function of mangroves for terrestrial and marine fauna: a review. Aquat Bot 89:155-185

Newman SP (2003) Spatial and temporal variation in diet and prey preference of nursery-bound juvenile lemon sharks (Negaprion brevirostris) at Bimini, Bahamas. PhD dissertation, University of Plymouth

Randall J (1967) Food habits of reef fishes of the West Indies, Vol 5. Institute of Marine Science, University of Miami, Coral Gables, FL

Ripple WJ, Beschta RL (2007) Restoring Yellowstone's aspen with wolves. Biol Conserv 138:514-519

Robertson AI, Blaber SJM (1992) Plankton, epibenthos and fish communities. In: Robertson AI, Alongi DM (eds) Tropical mangrove ecosystems. American Geophysical Union, Washington, DC, p 173-224

Rooker JR, Dennis GD (1991) Diel, lunar and seasonal changes in a mangrove fish assemblage off southwestern Puerto Rico. Bull Mar Sci 49:684-698

Rypel AL, Layman CA, Arrington DA (2007) Water depth modifies relative predation risk for a motile fish taxon in Bahamian tidal creeks. Estuaries Coasts 30:518-525

SAS (1990) SAS/STAT user's guide, Version 6, 4th edn, Vol 2. SAS, Cary, NC

Serafy JE, Faunce CH, Lorenz JJ (2003) Mangrove shoreline fishes of Biscayne Bay, Florida. Bull Mar Sci 72:161-180

Serafy JE, Valle M, Faunce CH, Luo JG (2007) Species-specific patterns of fish abundance and size along a subtropical mangrove shoreline: an application of the delta approach. Bull Mar Sci 80:609-624

Sih A (1980) Optimal behavior: can foragers balance 2 conflicting demands. Science 210:1041-1043

Sinclair ARE, Arcese P (1995) Population consequences of predation sensitive foraging: the Serengeti wildebeest. Ecology 76:882-891

Sogard SM (1992) Variability in growth rates of juvenile fishes in different estuarine habitats. Mar Ecol Prog Ser 85: 35-53

Starck W, Schroeder R (1970) Investigation on the gray snapper, Lutjanus griseus, Vol 10. University of Miami Press, Coral Gables, FL

> Sutherland WJ, Parker GA (1999) The link between interference and continuous input models. Anim Behav 57: 


\section{F19-F21}

Sutherland WJ, Townsend CR, Patmore JM (1988) A test of the ideal free distribution with unequal competitors. Behav Ecol Sociobiol 23:51-53

Thorson JM, Morgan RA, Brown JS, Norman JE (1998) Direct and indirect cues of predatory risk and patch use by fox squirrels and thirteen-lined ground squirrels. Behav Ecol 9:151-157

Tregenza T (1995) Building on the ideal free distribution. Adv Ecol Res 26:253-307

Unsworth RKF, Wylie E, Smith DJ, Bell JJ (2007) Diel trophic structuring of seagrass bed fish assemblages in the Wakatobi Marine National Park, Indonesia. Estuar Coast Shelf Sci 72:81-88

Valeix M, Loveridge AJ, Chamaille-Jammes S, Davidson Z, Murindagomo F, Fritz H, Macdonald DW (2009) Behavioral adjustments of African herbivores to predation risk by lions: spatiotemporal variations influence habitat use. Ecology 90:23-30

> Valentine JF, Heck KL, Blackmon D, Goecker ME and others (2007) Food web interactions along seagrass-coral reef boundaries: effects of piscivore reductions on crosshabitat energy exchange. Mar Ecol Prog Ser 333:37-50

van der Merwe M, Brown JS (2008) Mapping the landscape of fear of the Cape ground squirrel (Xerus inauris). J Mammal 89:1162-1169

Editorial responsibility: Ivan Nagelkerken, Nijmegen, Netherlands van Baalen M, Sabelis MW (1993) Coevolution of patch selection strategies of predator and prey and the consequences for ecological stability. Am Nat 142:646-670

> van der Meer J, Ens BJ (1997) Models of interference and their consequences for the spatial distribution of ideal and free predators. J Anim Ecol 66:846-858

> Verweij MC, Nagelkerken I (2007) Short and long-term movement and site fidelity of juvenile Haemulidae in back-reef habitats of a Caribbean embayment. Hydrobiologia 592:257-270

> Vesakoski O, Merilaita S, Jormalainen V (2008) Reckless males, rational females: dynamic trade-off between food and shelter in the marine isopod Idotea balthica. Behav Processes 79:175-181

Werner EE, Gilliam JF, Hall DJ, Mittelbach GG (1983) An experimental test of the effects of predation risk on habitat use in fish. Ecology 64:1540-1548

> Wirsing AJ, Heithaus MR, Dill LM (2007) Fear factor: do dugongs (Dugong dugon) trade food for safety from tiger sharks (Galeocerdo cuvier)? Oecologia 153:1031-1040

Wirsing AJ, Heithaus MR, Frid A, Dill LM (2008) Seascapes of fear: evaluating sublethal predator effects experienced and generated by marine mammals. Mar Mamm Sci 24: 1-15

Wirsing AJ, Cameron KE, Heithaus MR (2010) Spatial responses to predators vary with prey escape mode. Anim Behav 79:531-537

Submitted: November 4, 2009; Accepted: July 9, 2010

Proofs received from author(s): August 23, 2010 